\title{
The Importance of Women in the Construction of Community Health
}

\author{
Alfonso García Martínez Lázaro Sánchez* and Mํㅡㄹ Antonia \\ University of Murcia, Spain \\ *Corresponding author: Alfonso García Martínez Lázaro Sánchez, Department of Philosophy, Faculty Member, Spain
}

\begin{tabular}{|c|c|}
\hline ARTICLE INFO & ABSTRACT \\
\hline $\begin{array}{l}\text { Received: 㓞 January 07, } 2020 \\
\text { Published: 幽 January 16, } 2020\end{array}$ & $\begin{array}{l}\text { Citation: Alfonso García Martínez Lázaro Sánchez, Ma Antonia. The Importance of } \\
\text { Women in the Construction of Community Health. Biomed J Sci \& Tech Res 24(4)-2020. } \\
\text { BJSTR. MS.ID.004078. }\end{array}$ \\
\hline
\end{tabular}

\section{Mini Review}

In recent years, women have been the main protagonists of citizen mobilization on a global level, creating initiatives both in very small local environments, such as campaigns worldwide impact. There are many who raise their voices in defense of human rights, equality and social justice through traditional platforms and also through internet based, in line AVAAZ and CitizenGO. This movement is fostering a climate in which gender equality and health earn interest topics for discussion and research. Inevitably, talk about women and equality leads us to revise the term "gender" for some authors constructed as "the explanation of gender inequality" (Lamas, 2006). We are aware of the long journey in this matter, because, although currently the health of women has become a hotbed of activity in the field of health, we can not forget that for years was largely absent. It is, therefore, that the woman responsible for his position in the world today who wants to enrich their community should be fully aware of two key strongholds by struggle, actively or passively, publicly or privately. The first combat discrimination in their living conditions. Second, focus on contributing to health promotion in their environment in a broad sense that goes far beyond that traditionally has been regarded as health.

\section{Gender Inequality in Health Determinates Versus Social Health}

While it is true that in countries women industrialized live longer than men, so is that they often have poorer health Annandale et al. [1,2], this is where gender inequalities in health become relevant in the attempt to understand this reality. And the
Millennium Development Goals (MDGs) emphasized improved quality of life for all people, and specifically in Goal 5 is urged governments to policy review that would facilitate equality and empowerment of women and girls all the world. This framework recognizes the social inequalities in health [3] and keep in mind that gender is presented as a social determinant of health that we must continue to insist that healthy lifestyles are guaranteed for all people without discrimination. But the reality is still another. Women may have poorer health because, among other reasons, to an attachment to the labor market weaker, lower socioeconomic status, lower participation in the public sphere [4]. As well as the double burden of paid work and domestic responsibilities [5]. For examples like these, it is clear that the woman, now more than ever, is to travel on delicate points of balance between many conflicting factors. Work vs. home vs. servility rights ... And it is a task that requires great value, very high levels of honest self-observation, and a formidable attitude towards health and promoting healthy life styles quality. Today it is recognized that health is subject to the specific characteristics of each social and cultural environment. The Commission for Social Inequalities in Reducing Health [6]. it showed that health can also be defined as "the daily source of wealth." In this sense the health promotion of the strengths and heritage with people, organizations and social groups to maximize their health, which enhances the ability of individuals, communities and peoples to maintain and promote health and welfare $[7,8]$.

\section{Health Promotion as Community Development}

As we see, promote health goes far beyond the aspect or outpatient hospital. It implies the ability to have a critical conscience 
and considered able to make their own decisions. A process that has to do with the characteristics and peculiarities of the specific areas where it is applied, whether Sudan and Norway, and aims to visualize and mobilize the wealth and heritage of a community. In this sense the young, old, single, daughters or wives women are presented as true health promoters for their involvement at the community level through different networks of support and its presence in the associations in which they participate. Promoting women's health with an area of socio-educational practice with great potential to increase the health of all population. This is true to such an extent that health promotion and social support have been correlated with increased longevity in both general community populations and people with various diseases, as well as better management of medical problems and use of preventive practices health [9-11], highlighting the importance of intergenerational relationships with women and positive health effects on themselves. Support networks promote involvement in community health and are aimed at changing the social determinants of health in order to promote community participation and training to generate professional, social and political changes aimed at health promotion.

\section{Spain and Policies of Gender Equality in Health}

Since las gender inequalities in health are mostly produced socially, women, and therefore the health of the whole society, can be positively influenced by policies that promote equality between men and women, including family policies (seeking to increase family welfare and promote reconciliation between paid work and family), but also others such as policies promoting equal opportunities in the market representation [12]. The need for gender equality policies is urgent today, and even if the focus is more on health, since these policies reduce gender gaps in overall mortality and cardiovascular causes (National Statistics Institute [INE], 2011) [13]. As well as gender inequalities in perceived health [14]. Recently, some studies have examined the effect of gender inequality in Europe (by country) health $[15,16]$. Highlighting the presence of inequalities significantly higher in traditionally southern European countries (such as Spain, Greece and Portugal), andhese countries are characterized by a strong "familialism". A model of family solidarity / relationship based on an asymmetrical division of labor by gender, low female participation in the labor market, women play an essential role in the care of relatives and limited provision of care and financial support under family by part of the state. Women with a relatively short holiday period related to children less extensive benefits and childcare services in other countries [17]. In addition, in the context of the current economic crisis, women have been pushed into the labor market, which can increase mostly domestic workload due to minimal support for child care and the limited contribution of men to housework [18]. Nationwide studies andl balance between the Equality Act and the economic crisis shows the greater weight of the latter in the situation of gender equality together with austerity policies [19].
This setback in equality policies is a matter of concern that must be revealed, so that gender equality policies in health are a real priority right now.

\section{Empowering Women As Agents of Health Promotion}

Perhaps women themselves are less aware of how much influence the social fabric of our immediate environment, and in a globalized world, still underestimate the extent of our influence. Government actions have therefore to deal with building healthy environments and consider population diversity, among other topics, seen from a perspective of systemic complexity [20,21], bearing in mind that invest in health promotion women benefit women themselves, and therefore the whole society. Although the supports and networks vary considerably from one country to another, there is an invariant previously mentioned, the woman is at a key point to exercise a clear effect on the health of your community. Therefore, using the tools that the state or groups of any kind will provide, you have the ability to start and improve a social fabric that always benefited will be seen, and immediately affect not only their immediate surroundings but in the generations to come.

\section{Conflict of interest}

We have no disclosure to make that qualifies as a conflict of interest.

\section{References}

1. Annandale E, Hunt K (2000) Gender Inequalities in Health. Open University Press, Buckingham, UK.

2. Espelt A, Font Bank L, Rodriguez Sanz M, Artazcoz L, Ferrando J, et al. (2010) Among older people in disability Southern European city in 2006: trends in gender and socioeconomic Inequalities. J Women's Health 19(5): 927-933.

3. Marmot M (2005) Social determinants of health Inequalities. Lancet 365(9464): 1099-1104.

4. Schnittker J (2007) Working more and feeling better: women's health, employment, family life and 1974-2004. American Sociological Review 72(2): 221-238.

5. Read JNG, Gorman BK (2010) Gender inequality and health. Annual Review of Sociology 36: 371-386.

6. Iyer A, Sen G, Östlin P (2010) Inequalities in health and Intersections: a review of the evidence. Gender equity in health: The shifting frontiers of evidence and action p. 70-95

7. Garcia A, Sanchez AM (2015) Promotion and Education for Health: Balance and Perspectives. A Morón (Coord.), Investigate and intervene in health education p. 17-30.

8. Carmona G, Lopez LA, Mendoza OJ, Oleaga I (2015) Impact of the economic crisis on health and the health system in Spain. Work document. Andalusian School of Public Health, Granada, Spain.

9. Glass TA, Dym B, Greenberg S, Rintell D, Roesch C, et al. (2000) Psychosocial intervention in stroke: amilies in recovery from stroke trial (FIRST). American Journal of Orthopsychiatry 70: 169-181.

10. Sánchez AM (2006) Some evidence of the effectiveness of health education. Social pedagogy: Interuniversity magazine 12: 87-100.

11. Garcia A, Sanchez AM (2014) Proposed methodology of health education for Cultural Diversity. A working tool: Method apprêt. Social and proceeded-Behavioral Sciences 132: 330-335. 
12. Borrell C, Palencia L, Muntaner C, Urquía M, Malmusi D, et al. (2013) Influence of macro policies on women's health and gender Inequalities in health. Epidemiologic Reviews 36(1): 31-48.

13. (2011) National Institute of Statistics [INE]. Active Population Survey. INE.

14. Goerlich Gisbert FJ (2016) Income distribution, economic crisis and redistributive policies. Bilbao: Fundación BBVA.

15. Dahlin J, Härkönen J (2013) Cross-national Differences in the gender gap in Subjective health in Europe: Does country-level gender equality matter? Soc Sci Med 98: 24-28.

16. Van de Velde S, Huijts T, Bracke P, Bambra C (2013) Macro-level gender equality and depression in men and women in Europe. Sociol. Health illn 35(5): 682-698.

ISSN: 2574-1241

DOI: 10.26717/BJSTR.2020.24.004078

Alfonso García Martínez Lázaro Sánchez. Biomed J Sci \& Tech Res

This work is licensed under Creative

Commons Attribution 4.0 License

Submission Link: https://biomedres.us/submit-manuscript.php
17. Thévenon O (2011) Family policies in OECD countries: a comparative analysis. Popul Dev Rev 37(1): 57-87.

18. Artazcoz L, Cuts I, Puig Barrachina V, Benavides FG, Escribà Agüir V, et al. (2013) Combining employment and family in Europe: the role of family policies in health. The European Journal of Public Health 24 (4): 649655.

19. Muñoz LG, Modroño PR (2012) Gender inequality in economic crisis Feminists Research 2: 113-132.

20. Tan Wen HJ, Awad N (2005) Health care and services delivery systems as complex adaptive systems. Commun. ACM 48: 36-44.

21. Lamas M (2006) Genre: some conceptual and theoretical details. Feminism. Transmissions and retransmissions. Taurus, Mexico.

$\begin{array}{ll}\text { BIOMEDICAL } & \text { Assets of Publishing with us } \\ \text { RESEARCHES } & \text { - Global archiving of articles } \\ & \text { - Immediate, unrestricted online access } \\ \end{array}$

